\title{
PERBANDINGAN PENGETAHUAN DAN SIKAP TENTANG IMUNISASI VAKSIN HPV PADA REMAJA PUTRI KELAS X MAN DENGAN REMAJA PUTRI KELAS X SMA N 5 KOTA BATAM
}

\author{
Comparison Of Knowledge And Attitude About Hpv Vaccine Immunization In \\ Adolescents Woman Of X MAN Class With Adolescents Woman Of X Class SMA \\ N 5 City Batam
}

\author{
Indah Mastikana ${ }^{\text {** }}$ \\ *I Program Studi Kebidanan, \\ STIKes Awal Bros Batam \\ Kepulauan Riau, Indonesia
}

*email: indahmst2@gmail.com

Kata Kunci:

Pengetahuan

Sikap

Imunisasi Vaksin HPV

Keywords:

Knowledge

Attitude

HPV Vaccine Immunization

\begin{abstract}
Abstrak
Pencegahan displasia atau pra kanker adalah pencegahan sebelum datangnya kanker serviks adalah dengan imunisasi vaksin. Program pencegahan kanker serviks menggunakan vaksinasi HPV seharusnya sudah diperoleh dan diketahui remaja perempuan dalam proses pendidikan baik dilingkungan sekolah maupun kampus serta melalui media cetak maupun elektronik.

Desain penelitian yaitu Deskriptif Analitik dengan pendekatan Cross Sectional. Teknik sampel menggunakan teknik non probability dengan jumlah sampel 86 remaja dari masing-masing kedua sekolah.

Hasil penelitian menunjukkan bahwa 86 remaja putri di SMA N 5 Kota Batam yang berpengetahuan baik 56 siswi (65.1\%), cukup 26 siswi (30.2\%) dan kurang 4 siswi (4.7\%) dan bahwa dari 86 remaja putri kelas X SMA N 5 Batam, sebanyak 78 siswi memiliki sikap yang positif $(90.7 \%)$ dan negatif 8 siswi $(9.3 \%)$, sedangkan hasil penelitian di MAN Batam menunjukkan bahwa dari 86 remaja putri yang berpengetahuan baik 42 siswi (48.8\%), cukup 38 siswi (44.2\%) dan kurang 6 siswi (7.0\%) dan dari 86 remaja putri kelas X MAN Batam, 48 siswi memiliki sikap yang positif (55.8\%) dan negatif 38 siswi (44.2\%) terhadap Imunisasi Vaksin HPV.

Kesimpulan dari hasil penelitian bahwa terdapat mayoritas pengetahuan remaja SMAN 5 dan MAN Batam memiliki pengetahuan yang baik dan sikap yang positif serta terdapat perbedaan pengetahuan yang bermakna dan tidak terdapat perbedaan sikap yang bermakna tentang imunisasi vaksin HPV.
\end{abstract}

\begin{abstract}
Prevention of dysplasia or pre-cancer is prevention before the arrival of cervical cancer is by Vaccine Imunization. The cervical cancer prevention program using HPV vaccination should have been obtained and known to young women in the educational process both at school and campus as well as through print and electronic media.

The research design is descriptive analytic with cross sectional approach. The sample technique used non probality techniques with a sample size of 86 adolescents from each of the two schools.

The resulth showed that og the 86 girls in SMA N 5 Batam City who had good knowledge, were 56 students (65.I\%), only 26 students (30.2\%) and less 4 students $(4.7 \%)$ and that out of 86 girls in class X SMA N 5 Batam, as many as 78 students had positive attitudes $(90.7 \%)$ and 8 student negative $(9.3 \%)$ while the resulth of research at MAN Batam showed that from 86 girls who had good knowledge of 42 students (48.8\%), quite 38 students (44.2\%) and less than 6 students (7.0\%) and of the 86 teenage girls of class X MAN Batam, 48 students had positive attitude (55.8\%) and 38 students (44.2\%) negative attitude toward HPV Vaccine Immunization.

The conclusion from the research results is that there is a majority of knowledge of adolescents SMAN 5 and MAN Batam have good knowledge and positive attitudes and there are significant differences in knowladege and there are no significant differences in attitude about $H P V$ vaccine immunization.
\end{abstract}




\section{PENDAHULUAN}

Penyakit kanker serviks merupakan masalah kesehatan yang penting bagi wanita di seluruh dunia. Kanker serviks (kanker leher rahim) adalah sel-sel tidak normal pada leher rahim, yaitu bagian bawah rahim yang menonjol ke dalam kelamin wanita. Kanker serviks pada stadium dini sering tidak menunjukkan gejala atau tanda yang khas, bahkan tidak ada gejala sama sekali (Nasir 2009: Yupi Nurhastuti 2013).

Kanker serviks merupakan keganasan yang terjadi pada leher rahim dan merupakan pembunuh nomor 2 wanita didunia setelah kanker payudara. Kanker ini telah menyerang lebih dari I.4 juta wanita di seluruh dunia (Depkes RI, 2012).

Menurut data dari badan kesehatan dunia WHO (World Health Organization) setiap tahun tidak kurang dari 250 jiwa wanita meninggal dunia akibat kanker serviks (Aulia 2012: Novi 2013). Sedangkan di Indonesia, dilaporkan oleh Depkes RI kanker serviks di diperkirakan 90-100 diantara 100.000 penduduk per tahun. Insiden kanker serviks mulai meningkat sejak usia 20 tahun dan mencapai puncaknya 50 tahun. Menurut data Kementrian Pemberdayaan Perempuan dan Perlindungan Anak, setiap harinya diperkirakan muncul 45-50 kasus baru dan sekitar 20-25 perempuan meninggal karena kanker serviks (Hediyani 2012: Novi 2013).

Adapun Provinsi dengan kejadian kanker serviks paling tinggi yaitu Provinsi Kepulauan Riau sebanyak 1.416 jiwa, Provinsi Maluku Utara, dan Provinsi D.I. Yogyakarta memiliki prevalensi kanker serviks tertinggi yaitu sebesar I,5 \% (Data Riset Kesehatan Dasar, 2013). Di kota Batam, Berdasarkan survei yang dilakukan oleh peneliti pada tahun 2015 terdapat 7 diantara 10 wanita yang datang melakukan pemeriksaan yang berhubungan dengan reproduksi dicurigai mengidap kanker serviks pada tahun 2015 (Dinkes Kota Batam, 2016). Kanker serviks menjadi keganasan leher rahim yang disebabkan oleh infeksi Human Papilloma Virus (HPV), dengan prevalensi sebesar 99.7\% (Sulistiowati dkk, 2014).
Berdasarkan pengakuan dr Gumilang Wiranegara, SpOG, FMIS di Rumah Sakit Awal Bros Batam, sebanyak 90 persen kasus kanker serviks disebabkan memiliki infeksi HPV (Dewangga, 2015). HPV merupakan virus yang merupakan faktor yang menyebabkan terjadinya gangguan sel serviks, gangguan anogenital (serviks, vagina, vulva, anal) serta kutil kelamin (Committee on Adolescent Health Care, 2015).

Kanker serviks dapat dicegah dengan melakukan imunisasi vaksin Human Papiloma Virus. Vaksin HPV khususnya di rekomendasikan untuk wanita dimulai dari masa remaja yang dimulai pada usia 9 tahun. Imunisasi vaksin HPV diwajibkan dilakukan, namun dalam kenyataannya hanya $33 \%$ remaja yang melakukan. Hasil analisis menunjukkan bahwa pengetahuan wanita khususnya remaja tentang HPV sebagai penyebab kanker serviks rendah (Committee on Adolescent Health Care, 2015).

Oleh karena itu, pengetahuan yang cukup sangat penting untuk mencegah terjadinya kanker serviks sedini mungkin. Pencegahan displasia atau pra kanker adalah pencegahan sebelum datangnya kanker serviks. Pencegahan agar terhindar dari virus HPV adalah dengan imunisasi vaksin. Vaksin akan membuat system kekebalan mengenali serta menetralisir virus saat virus tersebut masuk ke dalam tubuh melalui kekebalan yang diperoleh (Notoadmodjo 2003: Siti Nurjanah, dkk).

Perempuan usia remaja dan telah mengalami menstruasi harus mulai memperhatikan kesehatan reproduksinya. Program pencegahan kanker serviks menggunakan vaksinasi HPV seharusnya sudah diperoleh dan diketahui remaja perempuan dalam proses pendidikan baik dilingkungan sekolah maupun kampus serta melalui media cetak maupun elektronik. Secara umum, remaja perempuan mulai peduli dengan kesehatan reproduksi ketika rnemasuki kelompok usia remaja akhir, karena dalam usia tersebut remaja perempuan mulai mernpertimbangkan persiapan menuju proses bereproduksi dimana kesehatan alat reproduksi sangat 
penting untuk diperhatikan (Notoadmodjo 2003: Siti Nurjanah, dkk).

Dari hasil survey yang dilakukan peneliti, di Dinas Kesehatan Kota Batam tidak terdapat data/ laporan baik dari rumah sakit maupun puskesmas tentang imunisasi Vaksin HPV guna mencegah kejadian Kanker Serviks. Berdasarkan studi pendahuluan yang dilakukan peneliti di salah satu Sekolah Menengah Atas (SMA) Negeri 5 Batam, telah dilaksanakan sosialiasi yang berhubungan dengan Kanker termasuk kanker serviks tanpa diperkenalkannya mengenai Imunisasi Vaksin HPV di SMA N 5 Batam kepada seluruh siswa-siswi SMA N 5 Batam sebanyak satu kali pada tanggal 16 Januari 2016. Sedangkan berdasarkan studi pendahuluan yang dilakukan peneliti terhadap salah satu Sekolah Menengah Atas Berbasis keagamaan yaitu Madrasah Aliyah Negeri (MAN) I Batam, menyatakan bahwa seluruh siswa-siswi remaja putri kelas $\mathrm{X}$ belum pernah mendapatkan sosialisasi dan masih sangat buta terhadap kejadian kanker serviks serta Imunisasi HPV.

Berdasarkan latar belakang diatas, maka peneliti ingin melakukan penelitian tentang Perbandingan Pengetahuan dan Sikap tentang Imunisasi HPV Putri kelas X SMA N 5 Batam dan Remaja Putri kelas X MAN Kota Batam tahun 2016.

\section{METODOLOGI}

Jenis penelitian ini merupakan penelitian survei analitik dengan pendekatan cross sectional. Populasi dalam penelitian ini adalah remaja putri kelas X SMA N 5 sebanyak 86 orang siswi dari 180 remaja (dengan jumlah remaja laki-laki sebanyak II0 siswa) dan remaja putri kelas X MAN sebanyak 86 siswi dari I I 0 orang remaja (dengan jumlah remaja laki-laki 24 siswa), Jadi, jumlah sample yang diambil adalah sebanyak 86 remaja putri di SMA N 5 Batam dan 86 remaja putri di MAN Batam.

Teknik Pengumpulan Data dalam penelitian ini menggunakan data primer dari hasil pengisian kuestioner oleh responden yang dilakukan secara langsung oleh peneliti terhadap sampel penelitian.

\section{HASIL DAN PEMBAHASAN}

\section{Hasil Penelitian}

\section{Analisa Univariat}

a. Distribusi frekuensi pengetahuan remaja putri kelas $X$ tentang Imunisasi Vaksin HPV di SMA N 5 Kota Batam tahun 2016 dapat dilihat oleh :

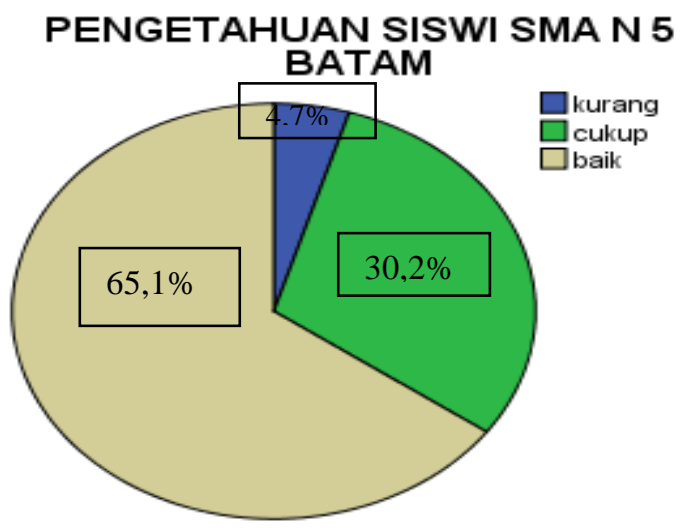

Diagram Distribusi frekuensi pengetahuan remaja putri kelas $X$ tentang Imunisasi Vaksin HPV di SMA N 5 Kota Batam tahun 2016

Dari diagram di atas menunjukkan bahwa dari 86 remaja putri di SMA N 5 Kota Batam memiliki mayoritas pengetahuan baik yaitu sebanyak 56 siswi (65.1\%) mengenai imunisasi vaksin HPV.

b. Distribusi frekuensi sikap remaja putri kelas $X$ tentang Imunisasi Vaksin HPV di SMA N 5 Kota Batam tahun 2016 dapat dilihat oleh :

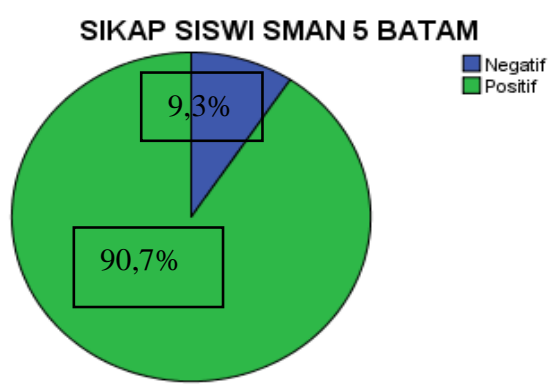

Diagram Distribusi frekuensi sikap remaja putri kelas $X$ tentang Imunisasi Vaksin HPV di SMA $\mathbf{N}$ 5 Kota Batam tahun 2016 
Dari diagram di atas menunjukkan bahwa dari 86 remaja putri kelas X SMA N 5 Batam, mayoritas memiliki sikap yang positif yaitu sebanyak 78 siswi $(90.7 \%)$ terhadap Imunisasi Vaksin HPV.

c. Distribusi frekuensi pengetahuan remaja putri kelas $X$ tentang Imunisasi Vaksin HPV di MAN Kota Batam tahun 2016 dapat dilihat oleh :

\section{PENGETAHUAN SISWI SEKOLAH MAN} BATAM

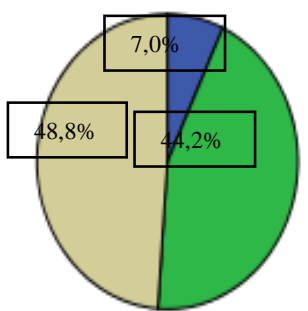

\section{口kurang \\ $\square$ cukup \\ $\square$ baik}

Diagram Distribusi frekuensi pengetahuan remaja putri kelas $X$ tentang Imunisasi Vaksin HPV di MAN Kota Batam tahun 2016

Dari diagram di atas menunjukkan bahwa dari 86 remaja putri di MAN Kota Batam memiliki mayoritas pengetahuan baik yaitu sebanyak 42 siswi (48.8\%) mengenai imunisasi vaksin HPV.

d. Distribusi frekuensi sikap remaja putri kelas $X$ tentang Imunisasi Vaksin HPV di MAN Kota Batam tahun 2016 dapat dilihat oleh:

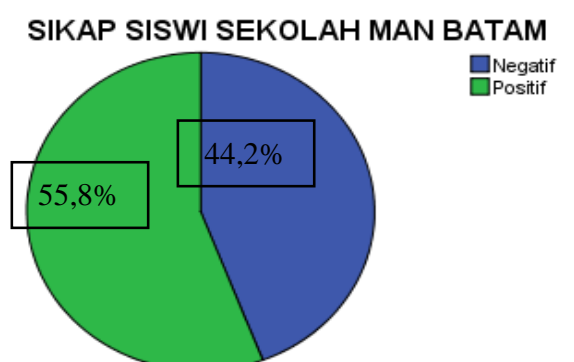

Diagram Distribusi frekuensi sikap remaja putri kelas $X$ tentang Imunisasi Vaksin HPV di MAN

\section{Kota Batam tahun 2016}

Dari diagram di atas menunjukkan bahwa dari 86 remaja putri kelas X MAN Batam, mayoritas memiliki sikap yang positif sebanyak 48 siswi (55.8\%) terhadap Imunisasi Vaksin HPV.

\section{Analisa Bivariat}

Di dalam penelitian ini, peneliti akan menggunakan uji chi square guna mengetahui tentang hubungan variabel dari masing-masing sekolah hingga nanti hasil yang didapatkan akan menjadi tolak ukur hasil inti dari penelitian.

a. Perbandingan pengetahuan SMAN 5 Batam dengan MAN Batam.

Tabel Perbandingan pengetahuan SMAN 5 Batam dengan MAN Batam

\begin{tabular}{|c|c|c|c|c|}
\hline Pengetahuan & \multicolumn{2}{|c|}{ SMAN 5 Batam } & \multicolumn{2}{|c|}{ MAN Batam } \\
\hline & Frekuensi & Persentasi & Frekuensi & Persentasi \\
\hline Baik & 56 & $(65,1 \%)$ & 42 & $(48,8 \%)$ \\
\hline 0.00 & & & & \\
\hline Cukup & 26 & $(30,2 \%)$ & 38 & $(44,2 \%)$ \\
\hline Kurang & 4 & $(4,7 \%)$ & 6 & $(7,0 \%)$ \\
\hline Jumlah & 86 & $(100 \%)$ & 86 & $(100 \%)$ \\
\hline
\end{tabular}
perbedaan yang bermakna antara pengetahuan SMAN 5 Batam dengan MAN Batam dengan nilai 0.00.

b. Perbandingan sikap SMAN 5 Batam dengan MAN Batam.

Adapun perbandingan sikap SMAN 5 Batam dengan MAN Batam dapat dilihat pada tabel berikut:

Tabel Perbandingan sikap SMAN 5 Batam dengan MAN Batam

\begin{tabular}{|c|c|c|c|c|c|}
\hline \multirow[t]{2}{*}{ Sikap } & \multicolumn{2}{|c|}{ SMAN 5 Batam } & \multicolumn{2}{|c|}{ MAN Batam } & \multirow[t]{2}{*}{ Sig } \\
\hline & Frekuensi & Persentasi & Frekuensi & Persentasi & \\
\hline Positif & 78 & $(90.7 \%)$ & 48 & $(55.8 \%)$ & 0.728 \\
\hline Negatif & 8 & $(9.3 \%)$ & 38 & (44.2\%) & \\
\hline Jumlah & 86 & $(100 \%)$ & 86 & $(100 \%)$ & \\
\hline
\end{tabular}

Dari tabel di atas menunjukkan bahwa tidak terdapat perbedaan yang bermakna antara sikap SMAN 5 Batam dengan MAN Batam dengan nilai sig 0.728 .

Pembahasan Penelitian

Univariat

a. Pengetahuan remaja putri kelas $X$ tentang Imunisasi Vaksin HPV di SMAN 5 Kota Batam tahun 2016.

Berdasarkan hasil penelitian menunjukkan bahwa dari 86 remaja putri di SMA N 5 Kota Batam yang berpengetahuan baik sebanyak 51 siswi (65.1\%), 
berpengetahuan cukup sebanyak 26 siswi (30.2\%) dan berpengetahuan kurang sebanyak 4 siswi (4.7\%) mengenai imunisasi vaksin HPV. Artinya, remaja putri kelas X SMAN 5 batam memiliki arah yang positif dalam memahami segala yang berkaitan dengan Imunisasi Vaksin HPV (Human Papiloma Virus) sebagai pencegahan kanker serviks.

$\mathrm{Hal}$ ini berhubungan dengan teori tentang pengetahuan khususnya faktor-faktor yang mempengaruhi pengetahuan menurut (Mubarok, 2007) yaitu pengetahuan dipengaruhi oleh pendidikan, pekerjaan, umur , minat, pengalaman, kebudayaan, informasi.

Dari hasil yang didapatkan oleh peneliti di lokasi penelitian, bahwa di SMAN 5 Batam memiliki sumbersumber yang banyak dalam memperoleh pengetahuan, termasuk tentang kesehatan. Bukan dari kegiatan akademik saja, pengetahuan didapatkan dari beberapa kegiatan-kegiatan yang berlaku seperti ekstrakulikuler, pramuka, hingga keorganisasian PMR (Palang Merah Remaja). Bukan hanya dari kegiatan internal, di sekolah SMAN 5 Batam tidak sedikit sosialisasi yang pernah dilakukan. Sosialisasi yang berasal dari luar lingkup sekolah dalam hal umum maupun berbasis kesehatan. Tentu hal ini sangat mempengaruhi pengetahuan siswa dan siswi remaja SMAN 5 Batam.

Selain itu, siswa siswi SMAN 5 Batam mempunyai antusias yang baik dalam menerima pengetahuanpengetahuan yang baru yang dapat di lihat dari sikap, minat dan cara siswa-siswi tersebut seperti aktif bertanya dan mau menceritakan pengalaman pribadi untuk mendapatkan ilmu-ilmu yang baru. Hal ini dapat menjadi bukti bahwa terdapat pengetahuan yang baik oleh remaja SMAN 5 Batam.

SMAN 5 Batam memiliki beragam prestasi, baik akademik maupun non akademik dari awal terbuka dan keaktifannya dalam menuntun para siswa dan siswi. Tidak sedikit beragam piala dan piagam penghargaan diberikan kepada siswa-siswi SMAN 5 Batam sebagai bukti bahwa siswa-siswi SMAN 5 Batam menjadi salah satu sorotan masyarakat dalam bentuk yang positif terkhusus dalam dunia pendidikan baik dalam bidang olahraga, kesehatan, seni, akademik, hingga fashion.

Selain itu, salah satu faktor pendukung pembentuk pengetahuan yang baik siswa-siswi SMAN 5 Batam adalah sarana dan prasarana yang memadai, dapat terlihat dari perpustakaan yang besar, lapangan yang luas, kelas tempat belajar siswa-siswi yang cukup, kelas khusus seperti kelas bahasa inggris yang dilengkapi dengan audio, masjid, hingga cctv yang terletak di setiap kelas, koridor, kantor dan kantin. Bukan hanya itu, sumber daya manusia sangat turut ikut serta berperan aktif dalam meningkatkan pengetahuan siswa-siswi SMAN 5 Batam, seperti guru-guru yang selalu memfasilitasi sebagai advokasi para siswa-siswi SMAN 5 Batam sehingga dapat terbentuknya siswa-siswi yang handal dan mempunyai minat serta motivasi dalam meraih pengetahuan apapun.

Pendidikan yang didapatkan di SMAN 5 Batam adalah pendidikan yang formal dan disertai kegiatan-kegiatan yang bersifat membangun, sehingga dapat meningkatkan pola fikir dan pengetahuan pelajar, terlebih lagi disertai dengan minat siswa-siswi SMAN 5 Batam dalam mengejar berbagai ragam informasi yang positif yang selalu didukung dengan pengalaman-pengalaman pribadi maupun pengalaman umum, usia yang reproduktif hingga informasi-informasi yang terus selalu mengalir dari pihak advokasi di sekolah. Tentu hal ini menjadi acuan penting dalam meningkatkan dan mempertahankan pengetahuan-pengetahuan yang baik oleh siswa.

\section{b. Sikap remaja putri kelas $X$ tentang Imunisasi Vaksin HPV di SMA N 5 Kota Batam tahun 2016}

Berdasarkan hasil penelitian menunjukkan bahwa dari 86 remaja putri kelas X SMA N 5 Batam, sebanyak 78 siswi memiliki sikap yang positif $(90.7 \%)$ dan 8 siswi yang memiliki sikap yang negatif (9.3\%) terhadap Imunisasi Vaksin HPV.

$\mathrm{Hal}$ ini menunjukkan bahwa remaja kelas X SMAN 5 Batam memiliki persepsi dan kemauan yang baik 
terhadap pentingnya imunisasi vaksin HPV sebagai pencegah kanker serviks sesuai dengan yang telah dikemukakan oleh Notoatmodjo tahun 2010, Sikap adalah merupakan reaksi atau respon seseorang yang masih tertutup terhadap suatu stimulus atau objek.

Sikap yang positif oleh siswa siswi SMAN 5 Batam dapat terlihat dari respon yang terjadi, seperti aktif bertanya, aktif berdiskusi dan tidak sungkan dalam menceritakan pengalaman-pengalaman pribadi yang bersangkutan dengan kesehatan. Selain itu siswi SMAN 5 Batam terlihat sangat bersemangat dan antusias dalam menggali informasi-informasi mengenai vaksin HPV.

Menurut Notoamodjo tahun 2010, pembentukan dan perubahan sikap akan ditentukan oleh dua faktor, yaitu: Faktor internal (individu itu sendiri) dan Faktor eksternal yaitu keadaan-keadaan yang ada di luar individu yang merupakan stimulus untuk membentuk atau mengubah sikap.

Didalam hal ini, sikap siswi SMAN 5 Batam dapat terbentuk dari dalam individu (diri sendiri), dan dari luar individu. Dari dalam individu, yaitu siswi SMAN 5 Batam sudah memiliki persepsi, komitmen, dan sudah memiliki tanggapan-tanggapan ataupun keinginan-keinginan tersendiri terhadap hal-hal yang dianggapnya baik ataupun buruk, termasuk tentang imunisasi Vaksin HPV. Sikap yang berasal dari dalam individu secara otomais akan sulit berubah karena sudah menjadi suatu karakter, terkecuali ada dorongan yang kuat dari pihak luar. Sebaliknya, sikap juga dapat terbentuk dan dipengaruhi dari luar (bukan dari dalam diri) seperti teman sepermainan, keluarga, tempat bersosialisasi sehari-hari maupun hal-hal yang dikagumi. Didalam hal ini faktor eksternal pembentuk sikap siswi SMAN 5 Batam yang positif dapat dibentuk dan dipengaruhi melalui sarana dan prasarana yang baik, advokator yang selalu memfasilitasi serta membimbing sehingga terbukti bahwa siswi SMAN 5 Batam memiliki sikap yang positif khususnya dalam bidang kesehatan mengenai Imunisasi Vaksin HPV.

\section{c. Pengetahuan remaja putri kelas $X$ tentang Imunisasi Vaksin HPV di MAN Kota Batam tahun 2016.}

Dari hasil penelitian menunjukkan bahwa dari 86 remaja putri di MAN Kota Batam yang berpengetahuan baik sebanyak 42 siswi (48.8\%), berpengetahuan cukup sebanyak 38 siswi (44.2\%) dan berpengetahuan kurang sebanyak 6 siswi (7.0\%) mengenai imunisasi vaksin HPV. Artinya, remaja kelas X MAN kota Batam memiliki ilmu yang bermanfaat dan pemahaman yang baik tentang imunisasi vaksin HPV.

Seperti yang diungkapkan oleh Notoadmodjo tahun 2012, bahwa pengetahuan merupakan hasil dari tahu, dan ini terjadi setelah orang melakukan pengindraan terhadap suatu objek tertentu. Pengindraan terjadi melalui pancaindra manusia, yakni indra penglihatan, pendengaran, penciuman, rasa, dan raba. Pengetahuan atau ranah kognitif merupakan dominan yang sangat penting dalam membentuk tindakan seseorang (overt behaviour).

Pada saat dilakukannya penelitian, beberapa siswi MAN Batam mengakui bahwa tidak banyak hal yang disinggung mengenai imunisasi vaksin HPV di tempat mereka belajar dikarenakan sekolah yang berbasis keagamaan haruslah lebih efektif dan teliti dalam menerima berbagai sumber dari pihak manapun untuk menjaga nama baik sekolah dan agama, serta untuk tetap mempertahankan dan menjadikan para siswa dan siswi menjadi berkualitas khususnya dalam bidang keagamaan hingga tidak mudah terpengaruh dengan dampak negatif era globalisasi . Namun, dari luar lingkup sekolah siswi MAN Batam memiliki banyak link dan ilmu yang didapat mengenai kesehatan, khususnya mengenai Imunisasi vaksin HPV. Hal ini didapatkan dari informasi-informasi yang beredar seperti dari media massa, dari pembicaraan orang lain dan dari referensi-referensi yang beredar. Tentu hal ini yang menyebabkan bahwa siswi MAN Batam memiliki pengetahuan yang baik mengenai Imunisasi Vaksin HPV. Walaupun berbasis keagamaan, remaja yang bersekolah di MAN tetap memiliki pengetahuan yang baik dalam 
memahami konsep yang berhubungan dengan pencegahan kanker serviks yang dapat disebabkan oleh pergaulan bebas pada remaja.

\section{d. Sikap remaja putri kelas $X$ tentang Imunisasi Vaksin HPV di MAN Kota Batam tahun 2016}

Berdasarkan hasil penelitian, bahwa dari 86 remaja putri kelas X MAN Batam, sebanyak 48 siswi memiliki sikap yang positif (55.8\%) dan 38 siswi yang memiliki sikap yang negatif (44.2\%) terhadap Imunisasi Vaksin HPV. Artinya bahwa remaja putri kelas X MAN Batam lebih banyak bersikap mengarah terhadap keinginan/respon tentang imunisasi Vaksin HPV.

$\mathrm{Hal}$ ini berhubungan dengan teori menurut Wawan, dkk tahun 2010, sikap mempunyai beberapa fungsi, salah satunya yaitu Fungsi instrumental (fungsi penyesuaian atau fungsi manfaat) yang berkaitan dengan sarana dan tujuan. Orang memandang sejauh mana obyek sikap dapat digunakan sebagai sarana atau alat dalam rangka mencapai tujuan. Bila obyek sikap dapat membantu seseorang dalam mencapai tujuannya, maka orang akan bersifat positif terhadap obyek tersebut. Demikian sebaliknya bila obyek sikap menghambat pencapaian tujuan, maka orang akan bersikap negatif terhadap obyek sikap yang bersangkutan.

Mengingat minimnya sosialisasi tentang imunisasi vaksin HPV di MAN, sikap yang positif terbukti dengan cara siswa-siswi MAN Batam dalam mencari informasi dari luar mengenai imunisasi Vaksin HPV.

\section{e. Perbandingan pengetahuan SMAN 5 Batam dengan MAN Batam.}

Dari hasil penelitian menunjukkan bahwa terdapat nilai $P$ value $0.00<0.05$ artinya bahwa ada perbedaan yang bermakna antara pengetahuan SMAN 5 Batam dengan MAN Batam. Hal ini dapat dikarenakan karena perbedaan pendidikan, minat, pengalaman, kebudayaan, informasi dari kedua sekolah tersebut (Mubarok, 2007). SMAN 5 Batam merupakan sekolah negeri berbasis umum dalam pembelajaran yang akan mempengaruhi minat dan pengalaman siswa dan siswi, kebudayaan/kebiasaan tentulah tidak akan jauh dari halhal yang umum, global dan mengikuti perkembangan zaman modernisasi tanpa memandang unsur khusus seperti keagamaan maupun adat. Informasi yang didapat pun juga sangat dekat dengan unsur-unsur yang global termasuk unsur kesehatan, faktanya remaja SMAN 5 Batam pernah mengikuti adanya sosialisasi tentang Kanker, termasuk kanker serviks pada tanggal I 6 januari 2016. Hal ini sangat mempengaruhi pengetahuan remaja SMAN 5 Batam dalam memperoleh pengetahuan.

MAN Batam merupakan sekolah negeri berbasis keagamaan (islami) hingga dalam pembelajaran sekalipun terfokuskan oleh islamiah. Oleh karena itu, minat dan pengalaman siswa maupun siswi dalam menerima pengetahuan tentulah lebih didominasikan oleh hal-hal yang menjorok dalam keagamaan. Kebudayaan akan dapat terlihat dengan tata cara dan adab siswa-siswi yang dituntut untuk menerapkan adab-adab yang dituntut dalam agama, termasuk dalam menerima informasi. Tentu hal ini sangat mempengaruhi pengetahuan remaja MAN Batam.

Ditambah lagi dengan minimnya sosialisasi tentang kesehatan khususnya Imunisasi Vaksin HPV di MAN Batam. Posisifnya, MAN Batam tetap memiliki angka yang bagus dalam memperoleh pengetahuan, dalam arti kata siswa-siswi MAN Batam cenderung memiliki gagasan, link yang luas terbukti dengan hasil pengetahuan yang baik mengenai imunisasi Vaksin HPV.

\section{f. Perbandingan sikap SMAN 5 Batam dengan MAN Batam.}

Dari hasil penelitian menunjukkan bahwa terdapat nilai $P$ value $0.728>0.05$ artinya ada perbedaan yang bermakna antara sikap SMAN 5 Batam dengan MAN Batam. Hal ini sangat berhubungan dengan teori yang dikemukakan oleh azwar, 2013 tentang faktor-faktor yang mempengaruhi pembentukan sikap antara lain diantaranya termasuk orang lain yang dianggap penting dan media massa.

Remaja yang berada di lingkungan kedua sekolah tersebut akan mempunyai masing-masing orang yang 
dianggap penting seperti orang tua dan teman sepermainan, akan menerima media massa secara bebas hingga akan mempengaruhi sikap remaja tersebut. Hal ini menunjukkan bahwa SMAN 5 dan MAN Batam memiliki sikap yang sama yaitu dalam segi positif mengenai imunisasi vaksin HPV, namun pada dasarnya kedua sekolah tersebut memiliki perbedaan dalam segi pembelajaran, kegiatan-kegiatan hingga sosialisasi yang diberikan.

Menurut Mulyana, 2015 ada beberapa faktor yang mempengaruhi sikap diantaranya sikap sebagai hasil belajar, yaitu sikap yang diperoleh melalui pengalaman yang mempunyai unsur-unsur tertentu. SMAN 5 dan MAN Batam mayoritas memiliki sikap yang positif mengenai Vaksin HPV namun memiliki perbedaan diantara keduanya, hal ini dipengaruhi oleh beberapa ketidaksamaan dari sistem pembelajaran akademik maupun non akademik dari kedua sekolah tersebut. SMAN 5 Batam memiliki sistem yang sangat terbuka mengenai ilmu pengetahuan apapun termasuk mengenai kesehatan reproduksi khususnya Imunisasi Vaksin HPV sedangkan sebaliknya bagi MAN Batam, pengembangan ilmu pengetahuan termasuk mengenai ilmu kesehatan reproduksi tidaklah bebas berkembang dikarenakan halhal yang menyangkut prinsip dan sistem pembelajaran ataupun aturan yang lebih mengutamakan unsur-unsur islamiah. Hal ini terbukti dengan beberapa mata pelajaran yang didominasikan oleh mata pelajaran islamiah di sekolah tersebut, namun masih dalam berupa komponen-komponen yang positif.

Dapat diambil kesimpulan bahwa di kedua sekolah tersebut memiliki hubungan yang sama dalam pembelajaran disekolah, secara garis besar akan menghasilkan komponen-komponen berupa didikan yang positif. Pengalaman-pengalaman remaja di kedua sekolah tersebut pun tidak berbanding jauh melihat era modernisasi dan globalisasi yang menyebar luas tanpa memandang agama, ras dan budaya.

\section{KESIMPULAN}

I. Pengetahuan remaja putri kelas $X$ tentang Imunisasi Vaksin HPV di SMA N 5 Kota Batam tahun 2016 menunjukkan bahwa dari 86 remaja putri di SMA N 5 Kota Batam memiliki mayoritas pengetahuan yang baik yaitu sebanyak 56 siswi (65.1\%) sedangkan Pengetahuan remaja putri kelas $X$ tentang Imunisasi Vaksin HPV di MAN Kota Batam tahun 2016 menunjukkan bahwa dari 86 remaja putri di MAN Kota Batam memiliki mayoritas pengetahuan yang baik yaitu sebanyak 42 siswi (48.8\%).

2. Sikap remaja putri kelas $X$ tentang Imunisasi Vaksin HPV di SMA N 5 Kota Batam tahun 2016 menunjukkan bahwa dari 86 remaja putri kelas $X$ SMA N 5 Batam mayoritas memiliki sikap yang positif yaitu sebanyak 78 siswi (90.7\%) sedangkan sikap remaja putri kelas $X$ tentang Imunisasi Vaksin HPV di MAN Kota Batam tahun 2016 bahwa dari 86 remaja putri kelas $X$ MAN Batam, mayoritas memiliki sikap yang positif yaitu sebanyak 48 siswi (55.8\%).

3. Ada perbedaan yang bermakna pada pengetahuan oleh remaja putri kelas $X$ SMAN 5 Batam dan remaja putri MAN Batam tentang imunisasi vaksin HPV dengan nilai signifikan chi square 0.00 .

4. Tidak ada perbedaan sikap yang bermakna pada remaja putri kelas X SMAN 5 Batam dan remaja putri kelas $X$ MAN Batam tentang imunisasi Vaksin HPV dengan nilai signifikan chi square 0.728 .

\section{UCAPAN TERIMA KASIH}

Tim penulis mengucapkan terima kasih kepada semua pihak yang telah membantu kelancaran pelaksanaan Penelitian ini di SMAN 5 dan MAN Kota Batam, dan segenap civitas akademika STIKes Awal Bros Batam dan Yayasan Awal Bros Bangun Bangsa. 


\section{REFERENSI}

I. Yupi, nurhastuti, 20I3. Faktor-Faktor yang Berhubungan Dengan Perilaku PUS Dalam Deteksi Dini Kanker Serviks Dengan Metode IVA Di Wilayah Kerja Puskesmas Kebumen I Kabupaten Kebumen.

2. Novi, desi yanti, 2013. Gambaran Pengetahuan Wanita Usia Subur Tentang Kanker Serviks di Lingkungan V Kelurahan Tanjung Gusta Helvetia Medan Tahun 20I3.

3. Eva, sulistiowati dkk, 20l4. Pengetahuan Tentang Faktor Risiko, Perilaku dan Deteksi Dini Kanker Serviks Dengan Inspeksi Visual Asam Asetat (IVA) Pada Wanita Di Kecamatan Bogor Tengah, Kota Bogor.

4. Committee on Adolescent Health Care, 2015. Human papillomavirus vaccination. Committee Opinion No. 641. American College of Obstetricians and Gynecologists. Obstet Gynecol 2015.

5. Rona, 2013. Hubungan Pengetahuan Wanita Usia Subur dengan Motivasi untuk Melakukan Pemeriksaan Pap Smear.Sibagariang dkk, 2010. 